tions regarding which diseases are most likely to be treated successfully by homeopathy. This list however is not derived from any conceptual framework nor does it seem to be related to the data in the section labeled clinical research. Similarly, in the chapter on healing touch, the author indicates that much of the evidence regarding ef- ficacy is based on anecdote which is no better than "wishful thinking." Yet, the author also states that therapeutic touch has changed the lives of many patients for the better.

In the foreword, former Surgeon General C. Everett Koop indicates that this is an opportune time to examine alternative treatments. After all, he con- tends, physicians must rely on empirical data when deciding on a treatment strategy. Those looking for a definitive presentation of the scientific data supporting alternative and complementary treatments may be disappointed in the volume. Those looking for a conceptual framework for understanding the field will find it very important.

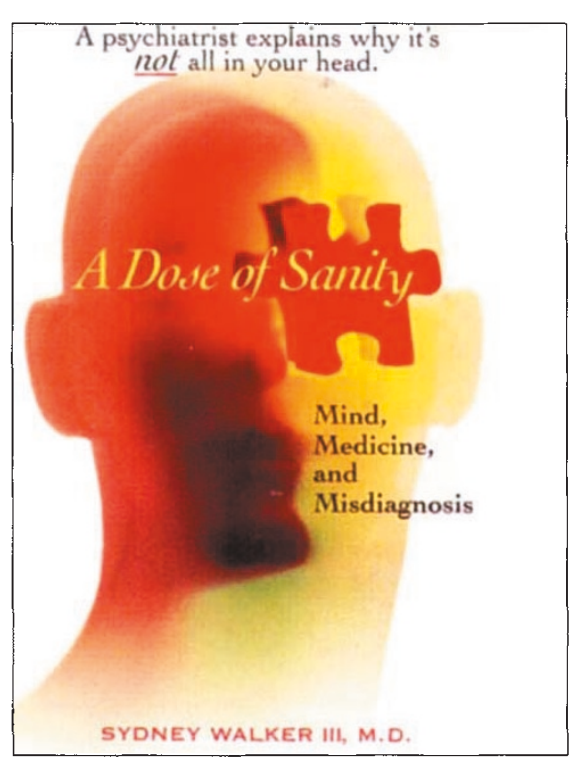

\section{A Dose of Sanity}

\author{
Sydney Walker, III \\ John Wiley \& Sons, Inc. \\ New York, New York
}

ISBN: 0-471-14136-4, 1996, \$19.95

\section{REVIEWED BY JeFFreY KellogG Washington, $D C$}

Anyone who has ever read Beowulf will recognize its structure in A Dose of Sanity almost immediately. Indeed the similarities between the two at times seem almost endless: there is a villain, the DSM (the American Psychiatric Association's Diagnostic and Statistical Manual of Mental Disorders); there is a hero, Sydney Walker himself; and, more notably, there is the voice - the writer telling the reader what he intends to tell the reader, then telling the reader, then telling the reader what has already been told.

This is unfortunate. For the book (at least the first half of it) is at times engaging and enlightening. Walker's exploration of DSM's history and the Machiavellian maneuverings behind its deliberations and revisions, for instance, makes for fascinating reading. And his basic argument - that the DSM has become a political document geared more toward description than diagnosis, and that its pervasiveness in medicine, the workplace, and courts of law actually harms, physically, psychologically and socially, the very people it presumes to help - is well taken. (Anyone who is familiar with this ponderous tome cannot but marvel at its vague generalities and horoscopic verbiage.) But to go on for 230 plus pages about it is tedious in the extreme.

The problem seems to be the author's lack of focus - not toward his subject (his emphasis on the DSM-as-root-of-all-evil is abundantly clear) but, rather, toward his audience. For while the first half of the book seems aimed at the more educated reader (readers familiar with the DSM and the process of deductive differential diagnosis), the second half, while returning again and again to the DSM's failure to "diagnose," seems geared more toward the Psychology Today-reading layperson. What began as a discussion of mind, medicine and misdiagnosis (as they relate to the DSM) dissolves into a diatribe against everything from the pharmaceutical industry to psychologists, from primal scream "therapy" to psychiatrists as legal "hired guns," and, of course, the DSM - which he again goes about debunking with McCarthyistic fervor and flair.

What is troubling is Walker's apparent all-or-nothing attitude. For while he has no problem pointing out the dangers inherent in what he calls the "DSM-anddrug" approach, he seems most often to be citing the exception rather than the rule. No one (no one with common sense, anyway) would push for Prozac as a "personality" pill or as a way to escape the everyday blues of living. After all, living entails suffering. But what about the thousands of people (major- and manic-depressives, for instance) who are now able to lead normal, productive lives precisely because of the availability of antidepressants, anticonvulsant mood-stabilizers, and other psychotropic drugs? Where do they fit in Dr. Walker's scheme of things? If one is to believe A Dose of Sanity, these people are the victims of nothing less than a monumental medical conspiracy. What he does tell us is this: these drugs are not cures. What he doesn't tell us is this: most psychiatrists worth their name would probably agree with him. Prozac (or any of the other antidepressants, for that matter) cannot "cure" major depression, but it can alleviate some of the sufferer's symptoms until its cause is determined and a "cure" is discovered.

So, where does this leave us?

The author suggests this: "the science of deductive differential diagnosis." According to Walker it is "time for psychiatrists to return to being physicians - not seers, priests, gurus or pill pushers, but real physicians." Psychiatry, he says, must return to its roots as a biologically oriented medical field and must "abandon the flaky idea that [we] are treating an invisible 'mind,' and realize that all of the emotional, behavioral, and thought problems [we] treat stem from disordered brain cells (neurons)." Accordingly, psychiatry must bring to bear all of its many resources and "accept the challenge of practicing 21 st-century medicine." Diagnosis must take precedence over description. And the brain must supplant the intangible "mind," as the organ of behavior. Only in this way can psychiatry reclaim its legitimacy and respectability.

This revolution, he writes, will require courage. For aligned against those who wish to change the system are those "astonishingly powerful" forces who wish to uphold "psychiatry's status quo." Thus "psychiatrists attempting to change the DSM system must be prepared to meet them head on" and to sacrifice. For physicians electing to go this route, he writes, will have to work harder and will probably make less money than they are making now. The alternative, however, is nothing less than psychiatry's iatrogenic death.

Again, his point is well taken. Indeed, as a whole, his book is an impassioned argument for a much needed change. Unfortunately it is a cautionary tale that reads too much like a critique. And his final call to arms, when it does come, comes so late one wonders if anyone will be around to hear it. 